\title{
Differences in the Structure of the Gut Bacteria Communities in Development Stages of the Chinese White Pine Beetle (Dendroctonus armandi)
}

\author{
Xia Hu, Chunyan Wang, Hui Chen * and Junning Ma \\ College of Forestry, Northwest A\&F University, Yangling 712100, Shaanxi, China; \\ E-Mails: lake-autumn@163.com (X.H.); chunyan@nwsuaf.edu.cn (C.W.); \\ mjn404@nwsuaf.edu.cn (J.M.) \\ * Author to whom correspondence should be addressed; E-Mail: chenhui@nwsuaf.edu.cn; \\ Tel./Fax: +86-29-8708-2083.
}

Received: 10 September 2013; in revised form: 12 October 2013 / Accepted: 14 October 2013 / Published: 18 October 2013

\begin{abstract}
The Chinese white pine beetle Dendroctonus armandi Tsai and Li, is arguably the most destructive forest insect in the Qinling Mountains in Northern China. Little is known about the structure of the bacterial communities associated with D. armandi even though this wood-boring insect plays important roles in ecosystem and biological invasion processes that result in huge economic losses in pine forests. The aim of this study was to investigate the composition of the bacterial communities present in the guts of $D$. armandi at different developmental stages using a culture-independent method involving PCR-denaturing gradient gel electrophoresis (DGGE). Analysis of PCR-amplified 16S rRNA gene fragments of bacteria from the guts of larvae, pupae, and male and female adults revealed bacterial communities of low complexity that differed according to the developmental stage. Citrobacter spp. and Pantoea spp. predominated in larvae and adults, whereas Methylobacterium was the dominant genus at the pupal stage. The main difference between the guts of male and female adults was the greater dominance of Citrobacter in females. Previous studies suggest that the bacterial community associated with $D$. armandi guts may influence insect development. The data obtained in this study regarding the phylogenetic relationships and the community structure of intestinal bacteria at different developmental stages of the $D$. armandi life cycle contribute to our understanding of $D$. armandi and could aid the development of new pest control strategies.
\end{abstract}

Keywords: bark beetle; bacterial community; symbiosis; DGGE; Dendroctonus armandi 


\section{Introduction}

Bark beetles, especially Dendroctonus species, are considered to be serious pests in coniferous forests [1]. They cause extensive damage to coniferous trees, which results in huge economic losses, and represent a major disturbance factor for the ecosystem [2]. Bark beetles can harbor gut microbial communities that range from simple to complex [3,4]. In a few systems that have been studied in more detail, important contributions to the host insect physiology and life history have been attributed to the gut-associated microbes [5,6]. The relationship between the nutrient-poor substrate on which the wood-boring insects feed and the cellulolytic and nitrogen-fixing microbes that are associated with these insects has also been investigated [7,8].

Chinese white pine beetle (Dendroctonus armandi Tsai and Li, Scolytidae), an important pest in the Qinling and Bashan Mountains in Northern China, is able to kill living Pinus armandi and has caused serious damage to $P$. armandi forests since 1954 [9]. Owing to the importance of $D$. armandi, various aspects of its biology and physiology have been studied, such as its niche within the $P$. armandi ecosystem [9], its life cycle [10] and symbiotic fungi [11]. However, little is known about its symbiotic intestinal bacterial communities.

Bacterial communities are known to play important roles in the life histories of bark beetles, contributing to their reproductive success, community interactions and niche diversification [12], as well as their development and survival in harsh environments by metabolizing toxins and providing protection against natural enemies [13]. Bacteria can also contribute to the fitness of bark beetles, particularly insects that rely on a nutrient-poor food source, by providing nutritional supplements that are absent from the diet of the insect, such as amino acids [14], essential vitamins [15] and nitrogen and carbon compounds $[16,17]$. Such relationships seem to be especially prevalent among insects that exploit woody substrates, which are relatively nutrient poor, heavily chemically defended, and available to competitors once the defenses of the woody substrate are depleted [18-20]. Host insects that are deprived of their symbiont show retarded growth, increased mortality and sterility [21]. Some endosymbionts have shown spatial and geographic variation [22,23]; however, it is poorly understood whether the composition of endosymbionts varies among the different developmental stages and between sexes. Hosokawa et al. first reported such a case in stinkbugs of the family Plataspidae, wherein specific gut bacteria were vertically transmitted via a "symbiont capsule" [24]. We hypothesized that beetles from all samples in our study would share a small number of bacterial species. We further hypothesized that there would be some relationships between bacterial community structure and the stage of development. The first step toward understanding the roles of endosymbiont community members in bark beetle biology and in the functioning of the community itself is to define the members of the community [25].

In our study, gut-associated bacterial communities of $D$. armandi in the larval, pupal and adult stages were investigated using a culture-independent method. We quantified the variability of bacterial communities and determined the frequency of specific bacterial phylotypes associated with the three developmental stages. Components of the bacterial community profiles were excised and sequenced to determine the identity of the taxa using PCR-denaturing gradient gel electrophoresis (DGGE) [26]. 


\section{Results and Discussion}

\subsection{Bacterial Diversity Analysis}

The number, density and composition of bacterial DGGE bands were different in each sample (Figure 1). Based on the peak density of bands in the DGGE profile, the bacterial diversity indices were analyzed as a way of estimating the diversity of microbial communities, which showed that the value of the Shannon-Wiener index $\left(H^{\prime}\right)$ was positively related to the diversity of the bacterial community. The richness and $H^{\prime}$ value (2.367476) of bacteria in the guts of $D$. armandi larvae (S1) were the highest with 16 visible bands in the DGGE profile, whereas the pupal stage (S2) was the lowest with only 10 visible bands (Table 1). There was no significant difference between the bacterial diversity of the larval and adult stages $(p>0.05)$, or that of the male and female adults $(p>0.05)$. The $H^{\prime}$ value of gut bacteria found in the pupal stage was significantly different compared with those of the larval and adult stages $(p<0.05)$.

Figure 1. Denaturing gradient gel electrophoresis (DGGE) profiles of nested PCR-amplified 16Sr RNA gene fragments of bacteria from the guts of Dendroctonus armandi larvae (lane S1), pupae (S2), adult females (S3), and adult males (S4). Bands P1-P22 and F1-F3 represent 16S rRNA gene regions of different bacteria.

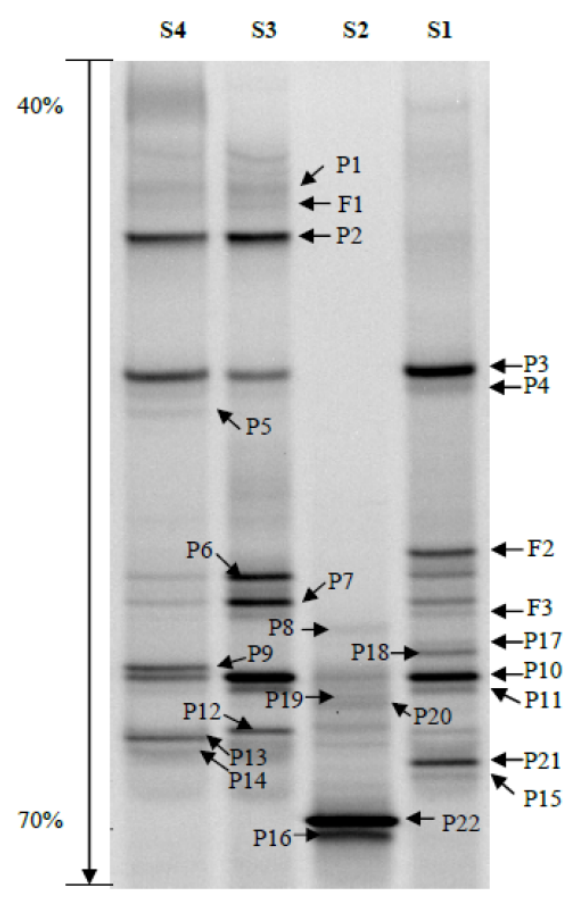

Table 1. Richness $(S)$, Evenness $\left(E_{H}\right)$ and Shannon-Wiener index $\left(H^{\prime}\right)$ of intestinal symbiotic bacteria identified in samples of Dendroctonus armandi at different developmental stages.

\begin{tabular}{ccccc}
\hline Lane & D. armandi sample & $\boldsymbol{S}$ & $\boldsymbol{E}_{\boldsymbol{H}}$ & $\boldsymbol{H}$ \\
\hline S1 & Larvae & 16 & 0.853886 & 2.367476 \\
S2 & Pupae & 10 & 0.649392 & 1.49528 \\
S3 & Female adult & 12 & 0.854255 & 2.122745 \\
S4 & Male adult & 14 & 0.885312 & 2.336389 \\
\hline
\end{tabular}




\subsection{Phylogenetic Analyses and Dominant Taxa}

Each of the distinguishable bands in the separation pattern represented an individual bacterial species [27]. In total, 25 different bands were successfully sequenced and two phylogenetic trees were constructed for the larvae and pupae (Figure 2A), and male and female adults (Figure 2B).

Sequence identification revealed that the majority of species were Proteobacteria ( $\gamma$-Proteobacteria, labeled P1-P18 and $\alpha$-Proteobacteria, labeled P19-P22 in Figure 1) and a few species were Firmicutes (labeled F1-F3 in Figure 1).

Figure 2. Phylogenetic trees of the bacterial communities in the gut of Dendroctonus armandi based on the 16S rRNA gene fragments. (A) Maximum likelihood phylogenetic tree of the bacterial community in the guts of larvae and pupae using the model Jukes-Cantor + I model; (B) Neighbor-joining phylogenetic tree of the bacterial community in the guts of female and male adults using the Kimura 2-parameter + G model. R1-R13 represent different operational taxonomic units with a 3\% sequence dissimilarity cut-off $\left(\mathrm{OTUs}_{0.03}\right)$ cluster obtained with MOTHUR.

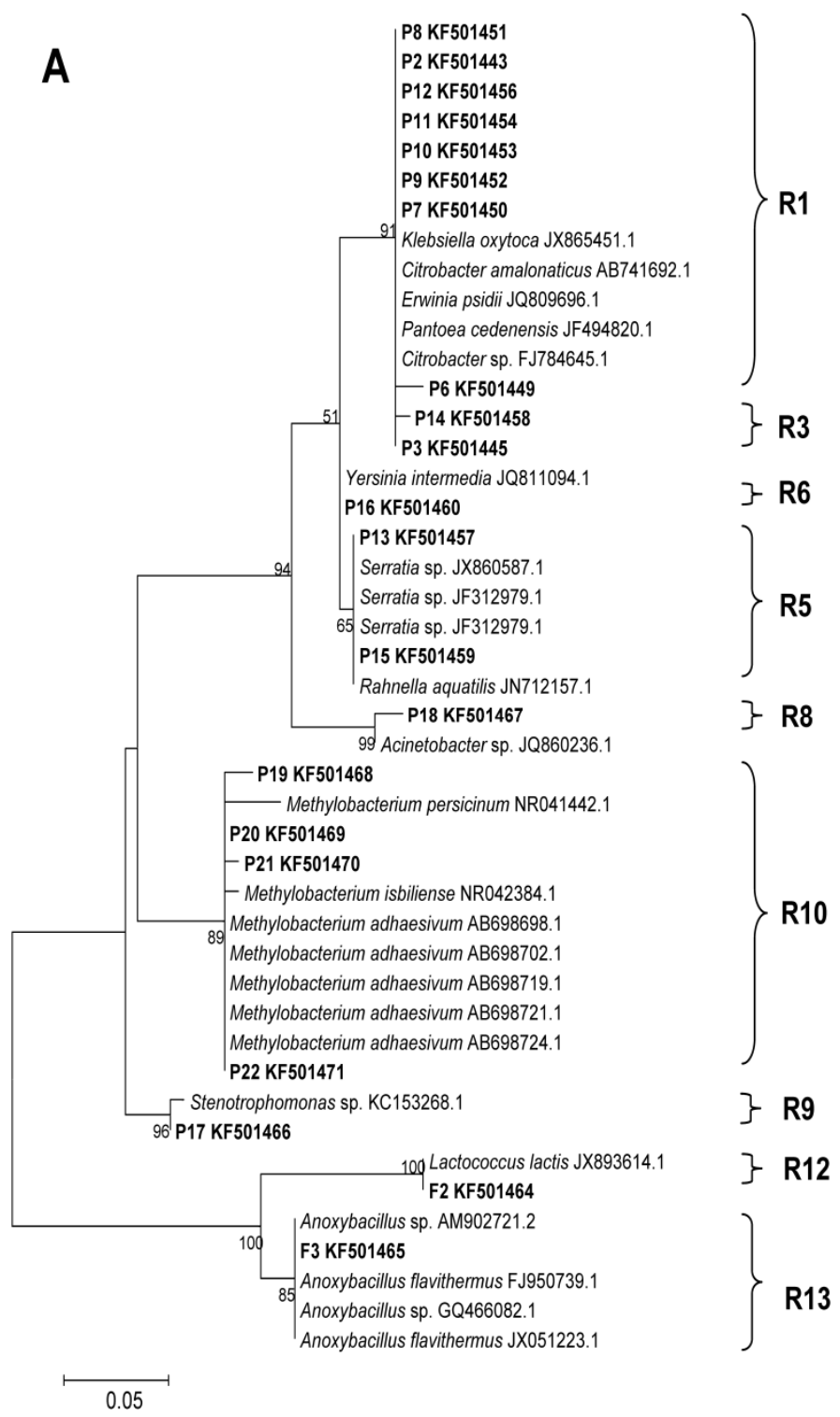


Figure 2. Cont.

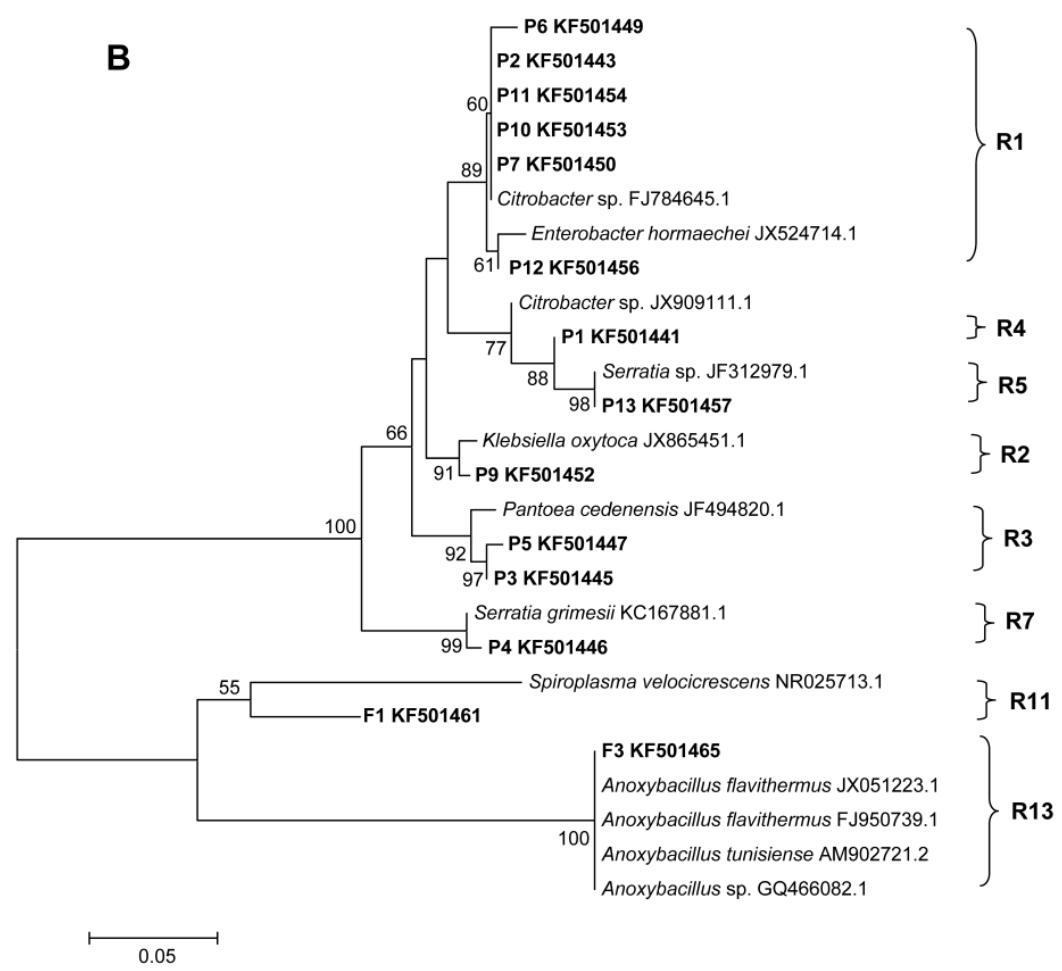

Citrobacter spp. and Pantoea spp. ( $\gamma$-Proteobacteria, Enterobacteriaceae) were the predominant bacteria in the guts of larval D. armandi, and Methylobacterium ( $\alpha$-Proteobacteria) predominated in the pupal guts. Both female and male adults contained a high proportion of Citrobacter. P2, P6, P7 and P10, which all belong to the Citrobacter genus, were the most distinct bands in the DGGE profile of bacteria from the guts of adult females (Figure 1). Band P3, which was identified as Pantoea, was the second most common bacteria in the guts of male adults (Figure 1).

\subsection{OTUs}

According to distance matrices of the sequences, 13 OTUs $_{0.03}$ clusters were obtained (R1-R13). R1 and R5 OTUs ${ }_{0.03}$ clusters were observed in the gut bacteria of all the samples (Figure 2). Sequences belonging to the R1 and R5 clusters grouped together on the same phylogenetic branch, and were closely related to Citrobacter and Serratia, respectively. In addition, cluster R1 was the most dominant group in all the samples except those from pupae, which were dominated by the R10 cluster, which comprised Methylobacterium spp.

The Chao index was used to better characterize the relative bacterial species richness of the different developmental stages and sexes of D. armandi. The OTU and richness estimation data revealed that the bacterial community structure was simplest in the pupal guts (Figure 3), with five OTUs o $_{0.03}$ clusters (R1, R2, R5, R6, R10) belonging to $\gamma$-Proteobacteria and $\alpha$-Proteobacteria (Figure 2A). Bacterial species richness was highest in larval guts, with nine OTUs $_{0.03}(\mathrm{R} 1, \mathrm{R} 3, \mathrm{R} 5, \mathrm{R} 7, \mathrm{R} 8, \mathrm{R} 9, \mathrm{R} 10, \mathrm{R} 12, \mathrm{R} 13)$ belonging to $\gamma$-Proteobacteria, $\alpha$-Proteobacteria and Firmicutes (Figure 2A). Seven OTUs $\mathrm{s}_{0.03}$ clusters (Figure 2B), all belonging to Enterobacteriaceae ( $\gamma$-Proteobacteria), were found in the guts of female adults (R1, R3, R4, R5, R7, R10, R13) and male adults (R1, R2, R3, R4, R5, R7, R10). 
Figure 3. Rarefaction curves of bacterial 16S rRNA sequences in the gut of Dendroctonus armandi larvae, pupae, adult females and males, calculated using MOTHUR OUTs $_{0.03}$. The plot showed the number of new bacterial species as a function of the number of clones sequenced.

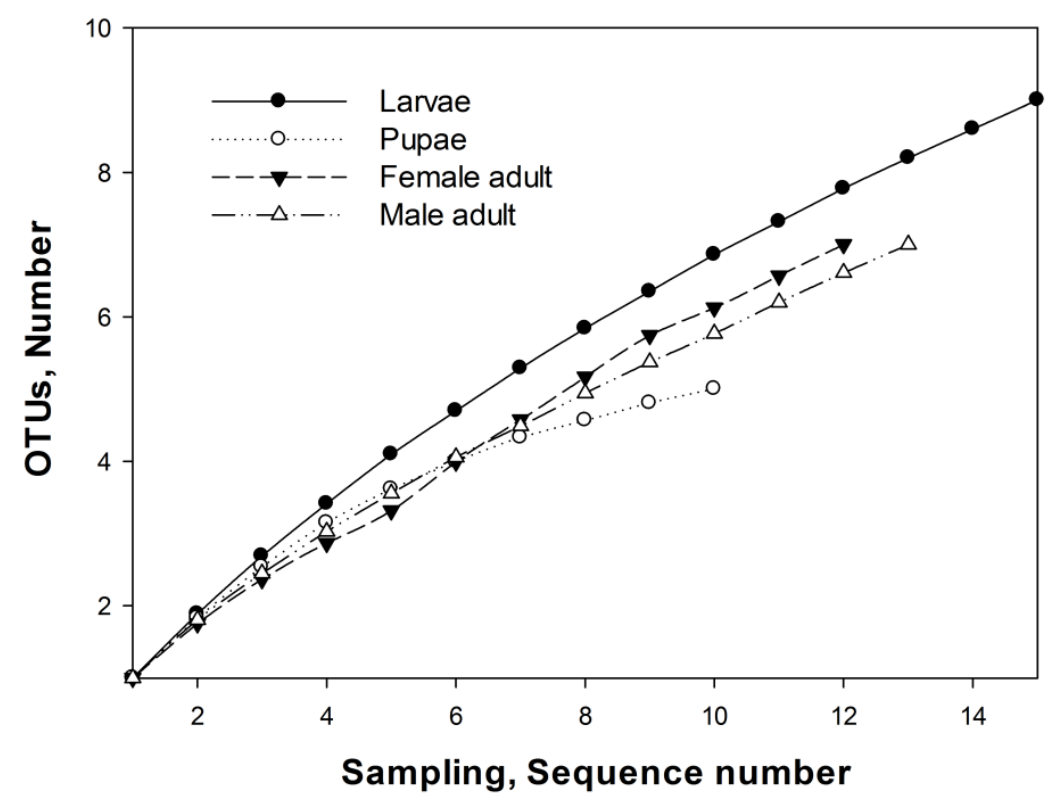

\subsection{Bacterial Community Structure}

This study has provided new insight into the gut bacterial diversity of $D$. armandi at different developmental stages and in the different sexes. Overall, the results of the bacterial diversity indices were consistent with the OTU richness estimation. The predominant species found in the intestinal bacterial communities of $D$. armandi formed a group of low complexity; however, the structure of the bacterial community differed depending on the developmental stage. A low level of bacterial community complexity in insect guts seems to be the norm [28-32], although there are some exceptions, for example, termite guts [33]. As we hypothesized, the gut-associated bacteria from all samples comprised only a few bacterial species. Citrobacter (R1) and Serratia (R5), which belong to the Enterobacteriaceae ( $\gamma$-Proteobacteria), were present in all samples from $D$. armandi guts. These conserved bacterial communities of shared bacterial taxa should be well adapted to their host. Members of the Enterobacteriaceae are commonly found in the gut communities of a wide range of animals, including humans and insects, and can aid in vitamin biosynthesis, pheromone production and degradation of plant compounds [34,35].

Citrobacter and Pantoea were the most abundant taxa in the guts of larvae and adults. The highest levels of Citrobacter were found in the guts of female adults. A range of different bacterial communities have been reported to be associated with bark beetles (Dendroctonus spp.), including Citrobacter spp. and Pantoea spp. [20,36-38]. Previous studies have reported that Citrobacter spp. and Pantoea spp. are associated with nitrogen fixation in the guts of termites and fruit flies (Ceratitis capitata) [39-41]. The abundance of Citrobacter in our study suggested that the nitrogen-fixing process could be an important dietary supplement of assimilable nitrogen for the bark beetle. In addition, Citrobacter sp. has also been shown to affect insect oviposition and larval development $[42,43]$, which might explain why the guts of 
adult females contained the highest levels of Citrobacter. To clarify the Citrobacter-Dendroctonus relationship, more studies are necessary to determine the nutritional status of this nitrogen-fixing bacterium in bark beetles.

Among the developmental stages investigated in this study, the pupal stage showed the simplest bacterial structure according to both the diversity indices and the Chao index. These results support previous findings of low bacterial diversity in the pupal guts of bark beetles [44].

Interestingly, Methylobacterium was the dominant taxa in the pupal stage. Species in the Methylobacterium genus are facultatively methylotrophic bacteria, and are mostly found in soil, as well as in the xylem and in other parts of plants $[45,46]$. They can use a variety of organic substrates with carbon-carbon bonds as sources of carbon and energy [47]. Most studies of the bacteria in this genus have focused on their roles in methane oxidization and the serine cycle. The role of gut-associated Methylobacterium spp. in D. armandi might be similar to that reported in studies of leafhopper and weevil, which feed on a complex carbon source $[45,46]$. Energy is required to achieve metamorphosis through the activation of several metabolic processes and morphological changes even though pupae do not feed. Therefore, the decline of bacterial diversity and the dominance of Methylobacterium spp. in pupae in this study could be associated with the absence of feeding activity and the necessity for pupae to extract the remaining energy from undigested food through the action of Methylobacterium spp. Methylobacterium spp. play an important role in the utilization of organic carbon sources and conversion of amino acids to support physiological activities in the pupal development stage. To clarify the Methylobacterium-Dendroctonus relationship, further studies are necessary to determine the role of this methane-oxidizing bacterial genus in the bark beetle life cycle.

The bacterial community structures found in the guts of adult males and females were similar, which supports similar findings in an earlier study [47], suggesting that the bacterial community structure in $D$. armandi adults is conserved. The bacterial communities in the adult guts belonged to the $\gamma$-Proteobacteria and Bacilli. Citrobacter was a dominant genus in both sexes, particularly in female adults. Our data suggest that although some of the bacteria found in the guts of adult bark beetles might relate to their sexual roles, most of the bacteria played similar roles in both sexes.

The information about bacterial community structure collected in this study will provide the basis for subsequent studies on the roles of these intestinal bacteria in bark beetle development, ecology and management. A study of the bacterial flora in the guts of Dendroctonus rhizophagus proposed that most of the bacterial genera present could be implicated in nitrogen fixation and cellulose breakdown, which are important roles associated with insect development and fitness, particularly given the challenging environment inhabited by the bark beetles [44].

Gut bacteria have been proposed as a means of achieving pest biocontrol. For example,

Enterobacter gergoviae, a gut bacterium of the pink bollworm (Pectinophora gossypiella), was transformed to express Cyt1A, an insecticidal protein lethal to mosquitoes and black fly larvae [48]. Plant surface bacteria have also been considered as biopesticide vectors to deliver insecticidal proteins to phytophagous insects [49]. The possibility of using the gut bacterium E. cloacae to control the mulberry pyralid (Glyphodes pyloalis) has also been successfully demonstrated by transforming the ice nucleation gene. An increased supercooling point was observed in G. pyloalis that had been colonized by the transformed gut bacteria, leading to an increased mortality rate [50]. Transgenic gut bacteria have even been used for the control of insect-borne human diseases, for example, transgenic Rhodococcus rhodnii 
has been used to control the triatomine bug Rhodnius prolixus, the vector of the medically important parasite Trypanosoma cruzi. [51]. Although there are scarcely any reports about using gut bacteria to control bark beetles, gut bacteria are a potential contender for pest biocontrol strategies in the future. Detailed knowledge about the dynamic variation, colonization and modes of transmission of intestinal bacteria is required before such a strategy could be successfully implemented.

\section{Experimental Section}

\subsection{Insect Collection and Dissection}

Larvae, pupae, and female and male adults of D. armandi were collected from the bark of infested P. armandi at the Huoditang Experimental Forest Station of the Northwest A\&F University in August 2012. The collection site was located on the southern slope of the middle Qinling Mountains $\left(33^{\circ} 18^{\prime}-33^{\circ} 28^{\prime} \mathrm{N}, 108^{\circ} 21^{\prime}-108^{\circ} 39^{\prime} \mathrm{E}\right)$, Shaanxi, China.

All the $D$. armandi samples were collected manually using fine forceps to extract the insects directly from the galleries of infested pine trees. The samples were transported to the laboratory in sterile vials containing sterile moist paper. To investigate the influence of sex on gut-associated bacteria, female and male adults were separated according to their reproductive organs.

Insect samples were rinsed in sterile water, surface sterilized with $70 \%$ ethanol for 3 min, and then rinsed twice in sterile water. After being placed in $10 \mathrm{mM}$ sterilized phosphate-buffered saline (138 $\mathrm{mM}$ $\mathrm{NaCl}$ and $2.7 \mathrm{mM} \mathrm{KCl}, \mathrm{pH} 7.4$ ), the insects were dissected under the stereomicroscope with the aid of insect pins to excise the mid-guts and hindguts [8]. Forty guts were excised from each of the developmental stages. Guts from the same development stage were transferred to a $1.5-\mathrm{mL}$ microcentrifuge tube, ground several times with a plastic pestle in liquid nitrogen, and then vortexed with $500 \mu \mathrm{L}$ of Tris-EDTA (10 mM Tris- $\mathrm{HCl}$ (pH 8.0), $1 \mathrm{mM}$ EDTA) for $3 \mathrm{~min}$ at maximum speed $(2500 \mathrm{r} / \mathrm{min})$ and then centrifuged at low speed $(4000 \mathrm{r} / \mathrm{min})$ for $15 \mathrm{~s}$ to separate microbial cells from the gut wall tissues and undigested food. The supernatant (containing bacteria) was transferred to new tubes for DNA extraction. All the procedures were performed in a sterile environment.

\subsection{Extraction of Bacterial DNA}

Bacterial DNA was extracted using the E.Z.N.A. Bacteria DNA Kit (Omega Biotech, Doraville, GA, USA) according to the manufacturer's directions, and then stored at $-20^{\circ} \mathrm{C}$ until needed.

\subsection{Nested PCR}

Nested PCR was used to increase the resolution yield of DGGE [52]. The highly variable V3 region of the bacterial 16S rRNA gene was amplified using primer pairs fD1 (5'-AGAGTTTGATCCTGG CTCAG-3') and rP1 (5'-ACGGTTACCTTGTTACGACTT-3') in the first round of PCR, and 341F-GC (5'-CGCCCGCCGCGCGCGGCGGGCGGGGCGGGGGCACGGGGGGCCTACGGGAGG CAGCAG-3') and 534R (5'-ATTACCGCGGCTGCTGG-3') in the second round of PCR [53]. All PCR amplifications were performed with a S1000 TM Thermal Cycler (Bio-Rad, Hercules, CA, USA) in a final mixture volume of $50 \mu \mathrm{L}$, containing $25 \mu \mathrm{L} 2 \times$ Taq Master Mix (CoWin Biotech, Beijing, China), 
$0.8 \mu \mathrm{L}$ of each primer $(10 \mu \mathrm{M}$, Invitrogen Trading, Beijing, China), $1 \mu \mathrm{L}$ template and $22 \mu \mathrm{L}$ RNase-free water.

The bacterial DNA was diluted to $30 \mathrm{ng} \mu \mathrm{L}^{-1}$ and used as the template for the first round of PCR, which was carried out using the following program: $94{ }^{\circ} \mathrm{C}$ for $3 \mathrm{~min}$, followed by 30 cycles, each at $94{ }^{\circ} \mathrm{C}$ for $1 \mathrm{~min}, 55^{\circ} \mathrm{C}$ for $1 \mathrm{~min}, 72{ }^{\circ} \mathrm{C}$ for $1.5 \mathrm{~min}$ and a final extension at $72{ }^{\circ} \mathrm{C}$ for $5 \mathrm{~min}$. The product of the first round of PCR was diluted $1 / 200$ with $\mathrm{ddH}_{2} \mathrm{O}$, and used as the template for the second PCR reaction, which was carried out using the following procedure: $94{ }^{\circ} \mathrm{C}$ for $3 \mathrm{~min}$, followed by 30 cycles of $94{ }^{\circ} \mathrm{C}$ for $30 \mathrm{~s}, 56{ }^{\circ} \mathrm{C}$ for $30 \mathrm{~s}, 72{ }^{\circ} \mathrm{C}$ for $30 \mathrm{~s}$ and a final step at $72{ }^{\circ} \mathrm{C}$ for $5 \mathrm{~min}$. The PCR products obtained and the primer specificity were analyzed by $1.2 \%(w / v)$ agarose gel electrophoresis and ethidium bromide staining in the presence of a DL2000 DNA marker (Takara Biotechnology, Dalian, China). The obtained PCR products were stored at $-20^{\circ} \mathrm{C}$ until DGGE analysis.

\subsection{Denaturing Gradient Gel Electrophoresis (DGGE)}

The DCode ${ }^{\mathrm{TM}}$ Universal Mutation Detection System (Bio-Rad) was used for the DGGE analysis. $35 \mu \mathrm{L}$ of bacterial nested-PCR products from each sample were loaded onto an $8 \%(w / v)$ poly-acrylamide (37.5:1 acrylamide/bio-acrylamide) gel containing a linear denaturing gradient of $40 \%$ to $70 \%$, where $100 \%$ denaturing acrylamide was defined as containing $7 \mathrm{M}$ urea and $40 \%$ formamide [54]. The gel was run at $120 \mathrm{~V}$ initially for $10 \mathrm{~min}$, and then $70 \mathrm{~V}$ for an additional $11 \mathrm{~h}$ at $58{ }^{\circ} \mathrm{C}$ in $1 \times$ TAE buffer (40 mM Tris-acetate ( $\mathrm{pH} 7.4), 20 \mathrm{mM}$ sodium acetate, $1 \mathrm{mM}$ disodium EDTA). After being stained with ethidium bromide solution for $10 \mathrm{~min}$, the gel was eluted in deionized water for $10 \mathrm{~min}$, and then photographed under UV light by using the Gel Doc ${ }^{\mathrm{TM}}$ XR System (Bio-Rad).

\subsection{DGGE Band Identification}

Dominant DGGE bands were excised from the poly-acrylamide gel and the DNA was eluted out using an E.Z.N.A. Mag-Bind Poly-Gel DNA Extraction Kit (Omega). The eluted DNA (1 $\mu$ L) was re-amplified with primer pair 534R and 341F without a GC clamp at the 5' end. The PCR products were purified using a Gel Extraction Kit (Baitaike Biological Technology, Xi'an, China), and connected to the plasmid pMD18-T vector (pMD18-T Cloning Kit, Takara Biotechnology, Dalian, China). The recombinant plasmids were transformed into Escherichia coli (strain DH5 $\alpha$ ) and the positive colonies were identified based on the blue-white screening. Five positive colonies were selected randomly from each transformation to further confirm the presence of correct inserts via PCR with the primer pair M13-47 and M13-48. The confirmed clones were sequenced (Jinsirui Biotechnology, Nanjing, China).

In order to determine the classification status of the intestinal bacteria, the sequences were matched with sequences in the RDP II database [55], and blasted in the NCBI database [56] and the EzTaxon-e database [57] to select and download the sequences that were reliable and that had a high sequence similarity. All the sequences obtained in this study have been submitted to the NCBI database (accession numbers KF501441-KF501471). Phylogenetic relationships among the intestinal bacteria were analyzed using molecular phylogeny techniques. Sequences were aligned using MUSCLE [58], available in the software MEGA 5, which computed the best model. The phylogenetic trees were constructed using Maximum Likelihood and Neighbor-joining methods [59]. To calculate the support for each clade, bootstrap analysis was performed with 1000 replications. 


\subsection{DGGE Band Profile Analysis}

The following procedure was used to analyze the DGGE band profiles using Quantity One software (Bio-Rad). First the auto frame lanes were selected and the rolling disk size was adjusted to five to minimize the influence of background. Second, the bands were detected and the parameters adjusted to acquire the most reliable band pattern, and then the Gauss-model was applied to all the lanes. Third, the lane with the most bands was selected using auto-match and the tolerance was set at $4.00 \%$; the other lanes were matched manually. Fourth, the peak density of all the lanes was reported for further analysis.

Each band was digitized via auto detection of peak density. Based on the transferred data, the diversity indices were calculated to investigate the dominant bacterial communities and to determine how they changed in the larvae, pupae, and adult females and males. Various indices of biodiversity, such as the Shannon-Wiener index $\left(H^{\prime}\right)$, Richness $(S)$ and Evenness $\left(E_{H}\right)$, were calculated from the DGGE patterns according to the following equations:

$$
\begin{gathered}
H^{\prime}=-\sum_{i=1}^{S} p_{i} \ln p_{i}=-\sum_{i=1}^{S}\left(N_{i} / N\right) \ln \left(N_{i} / N\right) \\
E_{H}=H / H_{\max }=H / \ln S
\end{gathered}
$$

where $S$ is the number of bands in a lane, $N i$ is the peak density of the $i$ th band and $N$ is the total peak density of all bands in a lane [60,61]. The significant differences between means were analyzed by $t$-test in SPSS Version 18.0 (SPSS Inc., Chicago, IL, USA).

\subsection{Operational Taxonomic Units and Richness Estimation}

Sequences in each phylogenetic tree were formatted to FASTA files and used to construct distance matrices for each library with MOTHUR Version 1.29.0 (Patrick Schloss, The University of Michigan, Ann Arbor, MI, USA). The distance matrices were used as the input files to define the OTUs on the basis of a similarity distance cutoff of 0.03 . OTUs defined by distances of 0.03 were generally corresponded to a species [62]. Sequences belonging to the same cluster based on the reference of OTUs $_{0.03}$ were grouped together in the phylogenic trees and labeled R1-R13 for the purpose of clarity (Figure 2). The Chao index [63] was calculated to measure the absolute value of species richness. Rarefaction curve methodology was used $[64,65]$ to estimate the relationship between the expected OTU richness and sampling depth. Finally, the rarefaction curves were generated using SigmaPlot Version 10.1 (Systat Software, Inc., San Jose, CA, USA).

\section{Conclusions}

This study revealed the structure of the gut-associated bacterial communities in the different developmental stages of $D$. armandi collected from the southern slope of the middle Qinling Mountains in August 2012. The predominant bacterial species varied during the life cycle of $D$. armandi. Several important bacteria were identified, including nitrogen-fixing and carbon transformation bacteria (Citrobacter, Pantoea and Methylobacterium), which are likely to play important roles at different developmental stages of the bark beetle. We propose that gut-associated bacteria could interfere with the development of $D$. armandi and, hence, may have potential as a vector for a biocontrol agent. 


\section{Acknowledgments}

We acknowledge the financial support of the National Natural Science Foundation of China (31170607, 31170567), the Program for Changjiang Scholars and Innovative Research Team in University of China (IRT1035).

\section{Conflicts of Interest}

The authors declare no conflict of interest.

\section{References}

1. Haack, R.A.; Slansky, F., Jr. Nutritional Ecology of Wood-Feeding Coleoptera, Lepidoptera, and Hymenoptera. In Nutritional Ecology of Insects, Mites, Spiders, and Related Invertebrates; Slansky, F., Jr., Rodriguez, J., Eds.; Wiley: New York, NY, USA, 1987; pp. 449-486.

2. Coulson, R.N.; Stark, R.W. Integrated Pest Management of Bark Beetles. In Bark Beetles in North American Conifers: A System for the Study of Evolutionary Biology; Mitton, J.B., Sturgeon, K.B., Eds.; University of Texas Press: Austin, TX, USA, 1982; pp. 315-349.

3. Cruden, D.L.; Markovetz, A.J. Microbial ecology of the cockroach gut. Annu. Rev. Microbiol. 1987, 41, 617-643.

4. Handelsman, J.; Robinson, C.J.; Raffa, K.F. Microbial Communities in Lepidopteran Guts: From Models to Metagenomics. In The Influence of Cooperative Bacteria on Animal Host Biology; McFall-Ngai, M.J., Henderson, B., Ruby, E.G., Eds.; Cambridge University Press: Cambridge, UK, 2005; pp. 143-145.

5. Dillon, R.J.; Vennard, C.T.; Charnley, A.K. Pheromones: Exploitation of gut bacteria in the locust. Nature 2000, 403, 851-851.

6. Moran, N.A.; Tran, P.; Gerardo, N.M. Symbiosis and insect diversification: An ancient symbiont of sap-feeding insects from the bacterial phylum Bacteroidetes. Appl. Environ. Microbiol. 2005, 71, 8802-8810.

7. Bridges, J.R. Nitrogen-fixing bacteria associated with bark beetles. Microb. Ecol. 1981, 7, 131-137.

8. Delalibera, I.; Handelsman, J., Jr.; Raffa, K.F. Contrasts in cellulolytic activities of gut microorganisms between the wood borer, Saperda vestita (Coleoptera: Cerambycidae), and the bark beetles, Ips pini and Dendroctonus frontalis (Coleoptera: Curculionidae). Environ. Entomol. 2005, 34, 541-547.

9. Chen, H.; Tang, M. Spatial and temporal dynamics of bark beetles in Chinese white pine in Qinling Mountains of Shaanxi Province, China. Environ. Entomol. 2007, 36, 1124-1130.

10. Yin, H.F.; Li, Z.L. Economic insect fauna of China. Coleopt. Scolyt. 1984, 29, 26-35.

11. Tang, M.; Chen, H. Effect of symbiotic fungi of Dendroctonus armandi on host trees. Sci. Silvae Sin. 1999, 35, 63-66.

12. Douglas, A.E. The microbial dimension in insect nutritional ecology. Funct. Ecol. 2009, 23, 38-47.

13. Adams, A.S.; Adams, S.M.; Currie, C.R.; Gillette, N.E.; Raffa, K.F. Geographic variation in bacterial communities associated with the Red Turpentine Beetle (Coleoptera: Curculionidae). Environ. Entomol. 2010, 39, 406-414. 
14. Nogge, G. Significance of symbionts for the maintenance of an optimal nutritional state for successful reproduction in hematophagous arthropods. Parasitology 1981, 82, 101-104.

15. Douglas, A.E. Nutritional interactions in insect-microbial symbioses: Aphids and their symbiotic bacteria Buchnera. Annu. Rev. Entomol. 1998, 43, 17-37.

16. Benemann, J.R. Nitrogen fixation in termites. Science 1973, 181, 164-165.

17. Dillon, R.J.; Dillon, V.M. The gut bacteria of insects: Nonpathogenic interactions. Annu. Rev. Entomol. 2004, 49, 71-92.

18. Cardoza, Y.J.; Klepzig, K.D.; Raffa, K.F. Bacteria in oral secretions of an endophytic insect inhibit antagonistic fungi. Ecol. Entomol. 2006, 31, 636-645.

19. Geib, S.M.; Filley, T.R.; Hatcher, P.G.; Hoover, K.; Carlson, J.E.; Del Mar Jimenez-Gasco, M.; Nakagawa-Izumi, A.; Sleighter, R.L.; Tien, M. Lignin degradation in wood-feeding insects.

Proc. Natl. Acad. Sci. USA 2008, 105, 12932-12937.

20. Morales-Jiménez, J.; Zúñiga, G.; Villa-Tanaca, L.; Hernández-Rodríguez, C. Bacterial community and nitrogen fixation in the red turpentine beetle, Dendroctonus valens LeConte (Coleoptera: Curculionidae: Scolytinae). Microb. Ecol. 2009, 58, 879-891.

21. Fukatsu, T.; Hosokawa, T. Capsule-transmitted gut symbiotic bacterium of the Japanese common plataspid stinkbug, Megacopta punctatissima. Appl. Environ. Microbiol. 2002, 68, 389-396.

22. Funk, D.J.; Bernays, E.A. Geographic variation in host specificity reveals host range evolution in Uroleucon ambrosiae aphids. Ecology 2001, 82, 726-739.

23. Tsuchida, T.; Koga, R.; Shibao, H.; Matsumoto, T.; Fukatsu, T. Diversity and geographic distribution of secondary endosymbiotic bacteria in natural populations of the pea aphid, Acyrthosiphon pisum. Mol. Ecol. 2002, 11, 2123-2135.

24. Hosokawa, T.; Kikuchi, Y.; Meng, X.Y.; Fukatsu, T. The making of symbiont capsule in the plataspid stinkbug Megacopta punctatissima. FEMS Microbiol. Ecol. 2005, 54, 471-477.

25. Broderick, N.A.; Raffa, K.F.; Goodman, R.M.; Handelsman, J. Census of the bacterial community of the gypsy moth larval midgut by using culturing and culture-independent methods. Appl. Environ. Microbiol. 2004, 70, 293-300.

26. Nocker, A.; Burr, M.; Camper, A.K. Genotypic microbial community profiling: A critical technical review. Microb. Ecol. 2007, 54, 276-289.

27. Cocolin, L.; Aggio, D.; Manzano, M.; Cantoni, C.; Comi, G. An application of PCR-DGGE analysis to profile the yeast populations in raw milk. Int. Dairy J. 2002, 12, 407-411.

28. Kuechler, S.M.; Dettner, K.; Kehl, S. Characterization of an obligate intracellular bacterium in the midgut epithelium of the bulrush bug Chilacis typhae (Heteroptera, Lygaeidae, Artheneinae). Appl. Environ. Microbiol. 2011, 77, 2869-2876.

29. Dillon, R.J.; Webster, G.; Weightman, A.J.; Charnley, A.K. Diversity of gut microbiota increases with aging and starvation in the desert locust. Anton. Leeuw. Int. J. G. 2010, 97, 69-77.

30. Lindh, J.M.; Terenius, O.; Faye, I. 16S rRNA gene-based identification of midgut bacteria from field-caught Anopheles gambiae sensu lato and A. funestus mosquitoes reveals new species related to known insect symbionts. Appl. Environ. Microbiol. 2005, 71, 7217-7223.

31. Lindh, J.M.; Lehane, M.J. The tsetse fly Glossina fuscipes fuscipes (Diptera: Glossina) harbours a surprising diversity of bacteria other than symbionts. Anton. Leeuw. Int. J. G. 2011, 99, 711-720. 
32. Weiss, B.; Aksoy, S. Microbiome influences on insect host vector competence. Trends Parasitol. 2011, 27, 514-522.

33. Hongoh, Y. Diversity and genomes of uncultured microbial symbionts in the termite gut. Biosci. Biotechnol. Biochem. 2010, 74, 1145-1151.

34. Breznak, J.A. Intestinal microbiota of termites and other xylophagous insects. Annu. Rev. Microbiol. 1982, 36, 323-323.

35. Xu, J.; Gordon, J.I. Honor thy symbionts. Proc. Natl. Acad. Sci. USA 2003, 100, 10452-10459.

36. Delalibera, I., Jr.; Vasanthakumar, A.; Burwitz, B.J.; Schloss, P.D.; Klepzig, K.D.; Handelsman, J.; Raffa, K.F. Composition of the bacterial community in the gut of the pine engraver, Ips pini (Say) (Coleoptera) colonizing red pine. Symbiosis 2007, 43, 97-104.

37. Winder, R.S.; Macey, D.E.; Cortese, J. Dominant bacteria associated with broods of mountain pine beetle, Dendroctonus ponderosae (Coleoptera: Curculionidae, Scolytinae). J. Entomol. Soc. Brit. Columbia 2010, 107, 43-56.

38. Morales-Jiménez, J.; de León, A.V.P.; García-Domínguez, A.; Martínez-Romero, E.; Zúñiga, G.; Hernández-Rodríguez, C. Nitrogen-fixing and uricolytic bacteria associated with the gut of Dendroctonus rhizophagus and Dendroctonus valens (Curculionidae: Scolytinae). Microb. Ecol. 2013, 66, 200-210.

39. French, J.R.J.; Turner, G.L.; Bradbury, J.F. Nitrogen fixation by bacteria from the hindgut of termites. Microbiology 1976, 95, 202-206.

40. Behar, A.; Yuval, B.; Jurkevitch, E. Enterobacteria-mediated nitrogen fixation in natural populations of the fruit fly Ceratitis capitata. Mol. Ecol. 2005, 14, 2637-2643.

41. Lilburn, T.G.; Kim, K.S.; Ostrom, N.E.; Byzek, K.R.; Leadbetter, J.R.; Breznak, J.A. Nitrogen fixation by symbiotic and free-living spirochetes. Science 2001, 292, 2495-2498.

42. Leroy, P.D.; Sabri, A.; Verheggen, F.J.; Francis, F.; Thonart, P.; Haubruge, E. The semiochemically mediated interactions between bacteria and insects. Chemoecology 2011, 21, 113-122.

43. Peterkova-Koci, K.; Robles-Murguia, M.; Ramalho-Ortigao, M.; Zurek, L. Significance of bacteria in oviposition and larval development of the sand fly Lutzomyia longipalpis. Parasit Vectors 2012, $5,145$.

44. Morales-Jiménez, J.; Zúñiga, G.; Ramírez-Saad, H.C.; Hernández-Rodríguez, C. Gut-associated bacteria throughout the life cycle of the bark beetle Dendroctonus rhizophagus Thomas and Bright (Curculionidae: Scolytinae) and their cellulolytic activities. Microb. Ecol. 2012, 64, 268-278.

45. Yamoah, E.; Jones, E.E.; Weld, R.J.; Suckling, D.M.; Waipara, N.; Bourdôt, G.W.; Hee, A.K.; Stewart, A. Microbial population and diversity on the exoskeletons of four insect species associated with gorse (Ulex europaeus L.). Aust. J. Entomol. 2008, 47, 370-379.

46. Gai, C.S.; Lacava, P.T.; Quecine, M.C.; Auriac, M.C.; Lopes, J.R.S.; Araújo, W.L.; Miller, T.A.; Azevedo, J.L. Transmission of Methylobacterium mesophilicum by Bucephalogonia xanthophis for paratransgenic control strategy of Citrus Variegated Chlorosis. Microbiology 2009, 47, 448-454.

47. Patt, T.; Cole, G.; Hanson, R. Methylobacterium, a new genus of facultatively methylotrophic bacteria. Int. J. Syst. Bacteriol. 1976, 26, 226-229. 
48. Kuzina, L.W.; Miller, E.D.; Ge, B.; Miller, T.A. Transformation of Enterobacter gergoviae isolated from pink bollworm (Lepidoptera: Gelechiidae) gut with Bacillus thuringiensis toxin. Curr. Microbiol. 2002, 44, 1-4.

49. Lilley, A.K.; Hails, R.S.; Cory, J.S.; Bailey, M.J. The dispersal and establishment of pseudomonas populations in the phyllosphere of sugar beet by phytophagous caterpillars. FEMS Microbiol. Ecol. 1997, 24, 151-157.

50. Watanabe, K.; Abe, K.; Sato, M. Biological control of an insect pest by gut-colonizing Enterobacter cloacae transformed with ice nucleation gene. J. Appl. Microbiol. 2000, 88, 90-97.

51. Beard, B.C.; Cordon-Rosales, C.; Durvasula, R.V. Bacterial symbionts of the Triatominae and their potential use in control of Chagas disease transmission. Annu. Rev. Entomol. 2002, 47, 123-141.

52. Xu, Z.; Tang, M.; Chen, H.; Ban, Y.; Zhang, H. Microbial community structure in the rhizosphere of Sophora viciifolia grown at a lead and zinc mine of northwest China. Sci. Total Environ. 2012, 435, 453-464.

53. Muyzer, G.; Hottenträger, S.; Teske, A.; Wawer, C. Denaturing Gradient Gel Electrophoresis of PCR-Amplified 16S rDNA-A New Molecular Approach to Analyse the Genetic Diversity of Mixed Microbial Communities. In Molecular Microbial Ecology Manual; Akkermans, A.D.L., Van Elsas, J.D., De Bruijn, F.J., Eds.; Kluwer Academic Publishers: Dordrecht, The Netherlands, 1996; pp. 1-23.

54. Muyzer, G.; De Waal, E.C.; Uitterlinden, A.G. Profiling of complex microbial populations by denaturing gradient gel electrophoresis analysis of polymerase chain reaction-amplified genes coding for 16S rRNA. Appl. Environ. Microbiol. 1993, 59, 695-700.

55. Cole, J.R.; Wang, Q.; Cardenas, E.; Fish, J.; Chai, B.; Farris, R.; Kulam-Syed-Mohideen, A.; McGarrell, D.; Marsh, T.; Garrity, G. The Ribosomal Database Project: Improved alignments and new tools for rRNA analysis. Nucleic Acids Res. 2009, 37, 141-145.

56. Wheeler, D.L.; Barrett, T.; Benson, D.A.; Bryant, S.H,; Canese, K.; Chetvernin, V.; Church, D.M.; DiCuccio, M.; Edgar, R.; Federhen, S.; et al. Database resources of the national center for biotechnology information. Nucleic Acids Res. 2007, 35, 5-12.

57. Chun, J.; Lee, J.H.; Jung, Y.; Kim, M.; Kim, S.; Kim, B.K.; Lim, Y.W. EzTaxon: A web-based tool for the identification of prokaryotes based on 16S ribosomal RNA gene sequences. Int. J. Syst. Evol. Microbiol. 2007, 57, 2259-2261.

58. Edgar, R.C. MUSCLE: Multiple sequence alignment with high accuracy and high throughput. Nucleic Acids Res. 2004, 32, 1792-1797.

59. Tamura, K.; Peterson, D.; Peterson, N.; Stecher, G.; Nei, M.; Kumar, S. MEGA5: Molecular evolutionary genetics analysis using maximum likelihood, evolutionary distance, and maximum parsimony methods. Mol. Biol. Evol. 2011, 28, 2731-2739.

60. Galand, P.E.; Fritze, H.; Yrjälä, K. Microsite-dependent changes in methanogenic populations in a boreal oligotrophic fen. Environ. Microbiol. 2003, 5, 1133-1143.

61. Lü, D.; Li, Z.; Qin, S.; Ma, H.; Liu, G. Bacterial community structure in the Cerasus sachalinensis Kom. rhizosphere based on the polymerase chain reaction-denaturing gradient gel electrophoresis (PCR-DGGE) method. Afr. J. Biotechnol. 2011, 10, 13430-13438.

62. Schloss, P.D.; Handelsman, J. Introducing DOTUR, a computer program for defining operational taxonomic units and estimating species richness. Appl. Environ. Microb. 2005, 71, 1501-1506. 
63. Chao, A.; Shen, T.J. Nonparametric estimation of Shannon's index of diversity when there are unseen species in sample. Environ. Ecol. Stat. 2003, 10, 429-443.

64. Gotelli, N.J.; Colwell, R.K. Quantifying biodiversity: Procedures and pitfalls in the measurement and comparison of species richness. Ecol. Lett. 2001, 4, 379-391.

65. Colwell, R.K.; Mao, C.X.; Chang, J. Interpolating, extrapolating, and comparing incidence-based species accumulation curves. Ecology 2004, 85, 2717-2727.

(C) 2013 by the authors; licensee MDPI, Basel, Switzerland. This article is an open access article distributed under the terms and conditions of the Creative Commons Attribution license (http://creativecommons.org/licenses/by/3.0/). 